\title{
Diasporic grief and grievance on-line: how South African and Serbian diasporas use the web
}

\author{
Eric Louw \\ Zala Volcic
}

\begin{abstract}
This paper explores the political and psychological angles of white South African and Serbian diasporas' discourses on-line. On the basis of textual analysis of diasporic web-sites we argue that participants speak of ongoing grievance over the loss of their countries and assert that they have been the victims of "unjust" history and globalisation. Each online discourse articulates claims of belonging not on the grounds of, for example, citizenship or multiculturalism, but rather on the basis of "a victim-hood", "civilisation", and "grief".
\end{abstract}

Key Words: anger, belonging, diaspora , identity, Serbia, South Africa, web-sites,

\section{Diasporic grief and grievance on-line: how South African and Serbian diasporas use the Web}

At the beginning of the $21^{\text {st }}$ century, mostly because of the changed nature of global conflicts, the rise of migrants and the use of new technologies, the political nature of migrants' belonging and attachment to the homelands has been fundamentally transformed. As Appadurai (2000) argues, on one hand, we witness the increased role of (local) media culture: everyday life rituals, representations, relationships, communication and information are all increasingly mediated, especially with the employment of the Internet. On the other hand, there is an increasing globalisation of communication, which has consequences for imagining and remembering "homelands" for diasporic communities. To study diasporas and media, then, is to explore a space that allows for the interrogation of belonging, emotions and identity in a way that seldom occurs in non-diasporic communities. The new circuits of on-line spaces provide the context in which migrants maintain or construct anew transnational interconnections that differ in their intensity and significance from the 'home' ties maintained by past migrations.

There is some excellent work on memories, diasporas, media, articulation, modernity, consumption and, moreover, on the relationship of memories and history. The close relationship between the ways in which diasporic imaginations, narratives, identities and articulations are used on the web is also well theorised (see, in particular, Aksoy, 2007; Appadurai, 2000; Jones, 1995; Sreberny, 2002; Chopra, 2006; Georgiou, 2001; Naficy, 1999; Skrbis, 1999; Gillespie, 1995). The literature identifies how diasporas use the Internet, and the most common arguments about the potential of Internet are, firstly, how the Internet presents a new vehicle for internal and external communication, for self-determination, and for resistance to outside cultural 
domination, such as negative stereotypes. Secondly, to many scholars (Aksoy, 2007; Chopra, 2006; Sreberny, 2002), the Internet offers a possible means - social, cultural and political - for reproducing and transforming cultural identity among people who have experienced massive political, geographic and economic disruption. Thirdly, the Internet is intended for both intercultural consumption and to cross over cultural boundaries. In that, diaspora re-appropriates media for purposes of a particular political/cultural revival and political reclamation (identifying relatives, land sites, etc.).... And lastly, the Internet makes it possible to communicate something about that social or collective identity we call "culture" in order to mediate across gaps of space, time, knowledge and prejudice (see more in Jensen, 2003 and Karim, 2003).

\section{Existing gap in the literature}

If an extensive body of research has analysed various aspects of on-line representations and discourses, only scant attention has been paid to the relationships between diasporas, the sense of belonging to the Heimat, globalisation, citizenship and psychological processes. Specifically, thus far the available literature regarding political diaspora in cyberspace is comprised of literature that engages mostly with themes related to the use of the Internet for nation-building (Tynes, 2007; Rai, 1995; Rheingold, 1993; Kollock \& Smith, 1999; Miller \& Slater, 2000; Spassov \& Todorov, 2003), and the use of the Internet by diasporic political/social movements abroad. For example, strength of the Kosovo Liberation Army (KLA) in 1998 may have been at least partially due to strong cyber-mobilisations of the Albanian diaspora in the West. But what has not been explored in-depth are the political and psychological angles of diasporic discourses on-line and their emotional dimension that cannot be reduced solely to the social. While there is now a huge body of research on the Internet, nationalism, and globalisation, the emotional underpinnings of conflicts tend to have been relatively unexplored by scholars who focus almost exclusively on the political, cultural and economic dimensions. In most of the literature, feelings such as guilt, shame, anger and humiliation tend to be reduced to political factors rather than analysed in their own right. The area of grief is then not extensively developed in relation to the Internet or in relation to ethnic/national conflicts. There is, however, a slow, but significant, trend of growing literature on media and emotions (Chouliaraki, 2006; Couldry, 2003), that this article attempts to contribute to.

All migrants experience some sense of dislocation and pain, but in order to think more productively about diasporas on-line, we focus here on websites and chat rooms where diasporic people express and vent their frustrations. This paper is thus an attempt to think through and against some assumptions and trends that have informed theories of the use of the Internet by diasporas.

After our initial research, where we conducted an analysis of various and diverse diasporic sites, we found out that since some diasporic people are physically separated from their homelands and, with that, from the wars and military conflicts, they continue to experience various kinds of emotions and develop different feelings. Mostly, in their articulations, they express anger, frustration and alienation. We started to pay close attention to those particular intense on-line expressions. We decided to limit ourselves to two diasporas, white South African ${ }^{\mathrm{i}}$ and Serb because these two diasporas appeared to share a number of characteristics. According to many 
(Karim, 2003), all migrants experience some sense of pain and emotional distress, but post-1990s Yugoslav/Serb and white South African diasporic people share a similar encounter with diasporic-ness. Both experienced deep social divisions - historical and current - along lines of class, race, ethnicity and religion. Both share the sensibility of "multiple dislocation" and the same sense of alienated dislocation that all other migrants experience (Verhulst, 1999; Karim, 2003). But in addition they have also lived through the collapse of a social order such that their former "worlds" and "lives" have disappeared. Such a "total" collapse generates an awareness of the fragility of social order (an awareness that is dislocating in itself). For the sake of methodological clarity then, we constructed a comparative framework - we acknowledge that the nature of diasporic politics is manifold and case-specific, but we saw some similar spaces being created that suggest a shared expression of specific feelings and long-distance belongings in these two cases. We see a shared feature of white South African and Serb diasporic identity as being their sense of belonging to political formations that no longer exist. They appear to be (traumatised) lost souls searching for the comfort of being embedded within a familiar identity. The problem they confront is that the identities they are searching for no longer exist because the identities they seek were those associated with political dispensations that have collapsed. The communities they search for are based upon memories grounded in another place and another time. The Serb identity they recall in their own interpretations was embedded within a Yugoslav state politically dominated by Serbs. And the white South African identity they remember was embedded within a South African political formation consisting of a white-ruled South African state and ten black-ruled homelands (Louw, 2004: 10-45). However, important to point out here is that while there is no doubt that Afrikaners and "Anglos" were a highly privileged and dominant group in all spheres of South African life during the apartheid era, as all available sociological data sets demonstrate, this was not the case for the Serbs in the former Yugoslavia in either economic, political or cultural domain. ${ }^{\text {ii }}$

The coming of a unified South African state ruled by the black majority and the break-up of Yugoslavia not only produced diasporic populations, it also produced diasporas traumatised and alienated in a particular way. We argue that there exists a particular type of on-line "anger" among the Serb and white South African diasporas which encodes resentment and envy about the current situation in their former countries. Both online diasporic communities, we suggest, voice their arguments in the language of anger. Furthermore, these diasporic sites speak of the ongoing grief and assert that they have been the victims of "unjust" history and globalisation. Each online discourse articulates claims of belonging not on the grounds of, for example, citizenship or multiculturalism, but rather on the basis of "a victim-hood", "civilisation" and "grief".

In what follows, we briefly provide some historical frameworks for understanding South African and former Yugoslav/Serb migrations. We explore both diasporic communities and on the basis of textual analysis of their websites argue that there is a prevailing anger among South African and Serb diasporic people on-line. This anger, as we suggest, has a double function in that it leads in two different (yet interconnected) emotional directions - grief and grievance. We explore these two notions and we show how the diasporic people use /represent Blacks/Muslims as their "other." 


\section{White South African and Serb diasporas in historical context}

Both the white South African and Serb diasporas were born of the same 1990s power-shift that followed in the wake of the collapse of the Soviet empire. During such upheavals many states disintegrate, or are radically restructured. In the process a new set of socio-economic winners and losers are generated. The losers often migrate, hereby creating particular diasporic populations. This is the case of both, former Yugoslavia and South Africa. Briefly, in former Yugoslavia, those people who had benefited from Tito's socio-economic order, and/or those associated with Tito's policy of encouraging a hybridised "Yugoslav" (inter-ethnic) identity, found themselves the losers within a post-Yugoslav order associated with the revival of ethnic identities. The collapse of the Soviet Empire produced a similar upheaval in South Africa where political power was transferred from white to black South Africans, such that, as Mbeki noted, the "burden of despair" (Mbeki, 2004) was shifted from blacks to whites. This has produced a white South African diaspora of people who see themselves as losers within the new socioeconomic order. ${ }^{\text {iii }}$

It is important to recognise that South African and Serb diasporas are the outcome of violent political conflicts. The 1976 Soweto revolt produced a significant exodus of both black and white South Africans. The post-1976 black exodus consisted of anti-apartheid activists fleeing into exile to establish external bases for guerilla warfare; while the post-1976 white exodus was driven by a belief that 1976 marked the start of a war that would eventually end white control of the political system. From 1984 to 1989 South Africa was wracked by political violence as pro and anti-apartheid forces fought each other. This 1984-1989 conflict generated another wave of migration - this time it consisted overwhelmingly of whites fleeing the violence. By 1989 the pro and anti-apartheid forces had fought each other to a draw. This produced an uneasy interregnum that coincidently coincided with the collapse of the Soviet empire.

Since the ANC came to power in 1994 there has been a steady increase in the size of the South African diaspora due to the exodus of white and Indian South Africans (Louw \& Mersham, 2001). During the 1990s this exodus was driven by the collapse of the criminal justice system; violent crime; the policies of Black Economic Empowerment (BEE) and Affirmative Action (AA). From 2006, additional spurs to migration were an assertive black nationalism (that promoted "Africanisation"; the elimination of Afrikaans and Anglo place-names; the downgrading of Afrikaans); plus infrastructural decline (such as the collapse of the electricity grid and hospital services) and the perception that corruption was endemic. The exact size of the South African diaspora is difficult to pin down but an estimated 20 percent of white South Africans have emigrated since 1990 (Van Aardt, 2006). The South African diaspora is largely concentrated in the United Kingdom, Australia, Canada, New Zealand and the USA.

Yugoslavia's bloody dissolution came about in 1990 (Banac, 1992). The collapse of socialism meant the disintegration of the federal state, wars and the formation of (seven!) new states. The wars of the 1990s were defined as the bloodiest conflicts in Europe since the end of World War II, resulting in an estimated 150,000 deaths and roughly four millions refugees (Skjelsbaek \& Smith, 2001; Lopusina, 1998). During the 1990s, the Serbs were escaping from the uncertain situation caused by the dissolution of Yugoslavia, the wars, as well as by economic crises, which 
largely affected the educated and skilled labor forces (i.e. "brain drain"). They increasingly migrated to Western Europe, North America and Australia/New Zealand. Altogether, there are, according to some estimation, currently around four million Serbs in diaspora throughout the world. For this research the most important is the last migration "wave" of Serbs during the 1990s, caused by wars and economic crisis in Yugoslavia.

Similarly, in both, South Africa and Serbia today, the social system is falling into disarray, and is characterised by unemployment, poverty and violence. Both remain deeply divided societies. For example, violent Serb protests in February 2008 against the Kosovo independence point to larger inequalities and divisions within the society. Precisely because the ANC and Serbian governments are seen to be incapable of maintaining law and order, there is a rise in emigration.

Consequently, Serb and South African diasporic people cannot re-construct the sort of (naïve) sense of "security" (that comes from believing in the "solidity" and "order" of one's social world). They experience a sense of permanent loss, and with that comes a sense of disorientation. They survived civil wars and so carry the baggage of having witnessed (and even participated in) political violence. They have had to reinvent themselves into the world of liberal-capitalism (a very different world view from their former political/economic worlds). Most importantly, as some of them point out on the Internet, others around them (in the host societies) do not (and cannot) understand their trauma or the worlds they come from. Koser and Lutz (1998) argue that because of the stronger cultural and political boundaries in Western states, contemporary diasporas have found full incorporation very hard, not possible or not desirable. This limits the possibility of communication and so encourages in-house communication within the diasporic community that locks "others" out and the diasporic people "in".

Important to argue here is that both Serb and South African diasporas are internally highly diverse, expressing different political views. It is crucial to differentiate between different groups of emigrants. For example there is a distinction between the Serbs from Serbia who emigrated in the early 1990s to avoid military draft and most of whom are not particularly sympathetic to the Serbian nationalism; the Croatian Serbs who emigrated mostly between 1995-7 after Croatia's reclaiming of its territory in Krajina and Vukovar regions and Kosovar Serbs who left after the war of 1999 both of which are much more nationalistic. Similarly there is a huge difference between the South African diasporas too: this is linked to the time of emigration (before and after apartheid) as well as to whether one belongs to "Anglo" or Afrikaners communities. However, for the purposes of this paper, we are not differentiating between these different groups - mainly because the web sites make it impossible to do so. This should be taken as a qualification and a cautionary note about the findings.

\section{'Angry' diasporic people on the Net}

In order to explore recurring themes in the diasporic cyber spaces, the websites for our analysis were carefully selected. ${ }^{\text {iv }}$ The methodology is that of close reading of selected virtual texts with reference to the cultural sociology of the technological practice of the diasporic South Africans and Serbs. Overall, 17 websites and listservs have been surveyed over the course of seventeen months. We focused, however, on the textual analysis of two websites, Homecoming Revolution 
and SrpskaDijaspora, precisely because they had the highest number of the active members. While identifying models of textual representation and expressions, this makes analytic comparison possible and patterns of interrelated concepts observable. Both, the Homecoming Revolution and SrpskaDijaspora sites are geared to promote a patriotic optimism. The chatrooms were created to encourage members to share with the others what they missed about home, why they were unhappy being away from home, if/why they wanted to return home ("the positives") and what prevented them from returning home ("the negatives"). Most white South African and Serbian diasporic people who made postings shared a number of common characteristics. We want to unpack these by focusing on two main themes - definitions of "self" and the "other"; and attitudes toward their country of origin. The discussion section focuses on the analysis of an expressed sense of grief and grievance, since most of the postings suggest a sense of loss (about losing their country) and also encode strong anger about their country being "taken away".

\section{Definitions of "self" and “other": guarding the frontiers of Western civilization}

Overall, both Serbs and white South Africans have seen themselves as guarding the frontiers of Western civilization. Their "self” definition was thus very much geared against others, where these "others" were understood as being of a fundamentally different culture - i.e. these "others" were seen as being firmly outside Western civilization. For the Serbs these "others" were Muslims (in most cases, either Bosnian or Kosovo Muslims), while for white South Africans, the "others" were black Africans. Interestingly, both Serbs and white South Africans have regarded themselves as involved in a "civilizational clash", where the roots of this clash were originally grounded in a sense of a "Christian mission".

Within the Serb narrative, Serbs are historically the defenders of Christian-Europe's southern boundaries against Muslim invaders (Ottoman Turks). Many posts focus on civilization, Orthodoxy and the importance of religion - and the role that the Serbs played in guarding civilized, Christian Europe against "barbaric" Islam. As posted by "Jovanka" (accessed 14 December 2008):

No one understands the Serbs! We are defending Europe against Islamic terrorism. We did it in the $16^{\text {th }}$ century, and we do it today, but the arrogant westerners do not get it even worse, they support the base of Islamic terrorism, the corrupt, criminal and tribal region of Kosovo...Europe now has muslim terroristic country (Kosovo) in the middle of it

Within the white South African narrative, white South Africans are seen as rugged pioneers who built a new Western nation (South Africa) in Africa. In this regard, white South Africans have traditionally seen themselves as comparable to Americans, Canadians, Australians and Argentineans who also build new European-derived nations (Van Jaarsveld, 1971:18-19). However, the white South African narrative includes the belief that white South Africans are actually morally superior to Americans, Australians, etcetera, because genocide was not carried out against indigenous South Africans as it was in places like the USA. Within their narrative, white South Africans came to see South Africa as a beleaguered outpost of Western civilization 
which it was their duty to stoically defend (Van Jaarsveld, 1971:428 \& 458-459). So, like the Serbs, white South Africans came to see themselves as defenders of one of the West's frontiers.

Furthermore, both Serbs and white South African have been confused and confounded that other Westerners (West Europeans and Americans) have failed to assist them in their (self-defined) role as the defenders of the West's frontiers (in the Balkans and in Southern Africa). And when Westerners have actually attacked them for fighting these "civilizational wars" both Serbs and white South Africans have often responded by adopting a victimhood narrative within which they see themselves as the victims of an alliance of forces that is undermining the interests of Western civilization. This narrative mixes confusion and irritation, which sometimes mutates into anger. As posted by 'Parazit' (accessed 5 January 2008), "I live now in Toronto, but I can honestly say that Serbia is a place of great culture, and great achievements, and I don't understand why we are perceived in the West as being uncultured..." 'Milos' (accessed 16 November 2008) continues in the same vein, arguing:

Let's face it, the US-EU-UN are nothing more than puppets of the rising Muslim tide spanning the globe. Money is power, and money dictates. Anyone who doesn't see this is naive. I hope to live to see the day when the US-EU and the like are split apart by these same Muslims that they are supporting. The US-EU have no shame in what they are doing. Americans are too stupid to realize. They obviously didn't learn there (sic) lesson with 9-11. Living in the US I see how dumb and un educated these people really are. That will be their undoing. Hopefully in the same manner

In a similar approach, in a posting on 12 November 2005, "Hometruths" vented frustration about Western double standards with regard to their perceptions of white South Africans (accessed 18 January 2008):

Apartheid policy has often been equated with genocide. An example is the so-called 'Sharpeville massacre'. Meanwhile in other parts of Africa shootings of civilian demonstrators are common occurrences, yet these are barely reported and quickly forgotten. When whites do something bad, especially to blacks, that is an atrocity to be picked over for eternity. If blacks do something bad it is quickly forgotten. The implication is clear - such behaviour is almost expected of blacks

While in another posting on 31 October 2005 "Hometruths" asked why the world condemned white South Africans and ignored the development that they had brought to Africa (accessed 7 February 2008):

When I google books about apartheid I get hundreds. They use every demon word in the corpulent lexicon of hyperbole. None ever has a single good word to say about the development of SA and of Africans by white administration. And yet even most liberals will privately admit that white rule brought development and black rule proved to be a disaster elsewhere in virtually every case. Whatever happened to the concept that there are two sides to every story? 
Many Serbs and white South Africans are currently deploying a narrative encoding a great deal of frustration and anger because they have lost control of what they see as "their territory". In the case of the Serbs this has seen Serb control of territory reduced to a state (Serbia) that is much smaller than the area inhabited by Serbs, and much smaller than the area Serbs were used to ruling (Yugoslavia). Especially in the case of a loss of Kosovo, this narrative comes out strong. Many posts, while discussing "losing" Kosovo, express anger, resentment, frustration and humiliation. The posts varied from being simple short angry statements, to being elaborated, coherent arguments about the injustice done to Serbia. As "Dragi" writes (accessed 18 February 2009):

What do Ottomans (Turks), Bulgarians, Hungarians, Germans, Austrians, Italians, Albanians and now Americans have in common? At some point in time they all came to Serbia to kill and expel Serbians. After so many centuries of doing those brave acts alone or in small groups they are finally having a reunion in Kosovo, "brothers in arms". They might spare few Serbs to emulate "multiethnic society" in EU "progress reports", and to show a good will they left few churches unburned to keep Serbians in their "natural inhabitat

In the case of white South Africans, the loss has been even more dramatic because the South African state is now politically dominated by black South Africans. As an ethnic minority, white South Africans have found themselves politically powerless since 1994 because the system of majoritarian-democracy has necessarily empowered the country's black-majority. As a result, the white South African self-definition has undergone a massive mutation since 1994 caused by the fact that white South Africans no longer control any national state of their own. White South Africans went from being the rulers of what they regarded as a Western state to being a beleaguered minority within a state that now defines itself as "African" and which is openly hostile to "Eurocentric" culture (Mbeki, 2003: 29). From within the white South African narrative (discussed above), the war to defend the frontier has been lost.

The Homecoming Revolution chatrooms became a meeting space where those who had opted to stay and had adopted a "development role" frequently clashed with those who had opted to leave South Africa. Hence, "Patriot" attached negative postings from the diasporic people on 27 July 2006 (accessed 22 December 2007) and exclaimed 'Come on!! Its time to make a meaningful difference in South Africa.' Similarly "nmumbi” attacked the negative postings on 14 August 2006 (accessed 26 December 2007) and said 'the people in SA, black and white, are trying to make it a better place.' At the other extreme were the postings from those who refused to adjust to the new black ruled South Africa because it had become culturally foreign. As "Rensburg" claimed (accessed 10 August 2007): 'The coming of the ANC has destroyed people's belief in South Africa as a heimat. SA under the ANC has become a foreign place to me, a place which I do not recognize as home anymore.' And on 3 November 2007 “Rensburg” added:

The destruction and co-option of Afrikaner assets (businesses, schools and universities) by the ANC makes it abundantly clear that there is no long term future for Afrikaners in SA. Thus logically the question Afrikaners have to answer is the following: Is it better to 
be anglicized in SA or in another Western democracy (where Afrikaners will not suffer BEE)

A feature of the conceptualisation of the "other" shared by both Serbs and white South Africans is that the "other" is deemed culturally inferior. Serbs have traditionally regarded "their" Christian civilization as superior to that of Muslims. As posted by "Oli" (accessed 22 March 2007):

Islam is [a] more violent and aggressive religion. It is fundamentalist in its nature, you see. Now, the problem lies in the fact that the Muslims do not accept secular regimes...because they are still living in the middle ages, more accepting of Koran and they still listen to their elders that came from Arabic dictatorships and have no idea about democracy and culture

A posting by "Boereseunnz" (accessed 6 July 2006) encoded this contempt for the "other": 'Planet of the Apes, with Robert Mugabe as the biggest Ape. Africa is a circus with monkeys as the clowns for the whole world to laugh at.'

On 27 October 2005, "hometruths" showed his contempt for the "other" when arguing that if whites were given an apartheid homeland they would make a success of it, whereas blacks had proved incapable of developing their homelands (accessed 12 August 2007):

At least the white government gave each tribe their own country. Of course the real reason the ANC will never give whites their own homeland is because such a white-rule enclave would be hugely successful

White South Africans have traditionally seen themselves as a people who brought Westerncivilization to Africa. The Afrikaner version emphasised the notion of being a people of the Bible who had brought Christian civilization into the African interior, while the Anglo South African version emphasised their role in bringing Western economic development to Africa. Both Anglos and Afrikaners viewed Western civilization as superior to the indigenous African cultures they encountered. Both have traditionally seen themselves as 'civilizing agents' (responsible for bringing civilization to South Africa). Further, within the white South African narrative, they see themselves as responsible for developing the country and take pride in having produced Africa's most developed state and economy. This narrative burst to the fore after a posting was made to Homecoming revolution by "patriot" in Cape Town, who called on his fellow whites to apologise for apartheid. On 4 August 2006 "jaguar" replied: "I would like to state that I am very sorry my father built up a business that employed and still employs hundreds of South Africans."

\section{Attitude to country of origin}

Massive changes have been wrought to both former Yugoslav countries and South Africa since 1990, changes that have turned the worlds of Serbs and white South Africans upside down. 
These changes have necessarily altered their sense of "self", their relationship to (and understanding of) "others", and their attitudes towards their own countries.

White South Africans have had to learn to see their country in a new way since 1994. In 1990 they were the rulers of what they regarded as a Western state. White South Africans have clearly had to reshape their relationship with their country in a completely new way - whereas before 1990 whites felt empowered to take decisions, they have now become largely passive observers of other people making decisions. Since 1994 white South Africans found themselves as an ethnic minority within a state ruled by black people. Furthermore, the new government defined the post-1994 state as "African"; suspicious of its "Eurocentric" past and explicitly geared towards using state power to transfer wealth from whites to blacks (through BEE and AA). As a minority, white South Africans found themselves powerless to challenge those policies. Their sense of political disempowerment was clearly deeply alienating, and has certainly been one of the factors driving white emigration. This sense of alienation is apparent in the voices using the Web, such as in the posting by "satellite" on 14 Aug 2006 (accessed 13 November 2007):

This BEE is a crock of .... And is the cause of most of the grief we have. This is how BEE goes when you want to employ someone: black (men \& women) first choice; any other colour (not whites) second choice; if it really needs to be then white female; only if you cannot fill it with any of the above and are really desperate - white male.

On 24 June 2006 "bad habit” revealed his/her alienation when posting:

I will come back when I am accepted as an 'African' no matter my skin colour. I will come back when there is equal opportunity for all, and the colour of your skin does not make a difference. I will come back when the Minister of Health acknowledges there is an AIDS problem. I will come back when my family do not have to live behind barbwire. I will come back when there is a well paid, efficient and trained police force

Black-African culture is seen as so alien, that white South Africans have consistently rejected the idea of integrating with black-Africans. And although white South Africans have lost political power, the postings to the Web suggest, they still regard Western culture as culturally superior to black-African culture. The white South African narrative has long encoded a pride about having produced Africa's most developed state and economy. White South Africans see this county/economy as their product - as something they build out of a wilderness. Hence in the new white South African narrative there is much resentment that black South Africans (using the discourses of socialism, black nationalism, BEE and AA) are now using state power to grab what white South Africans believe they built. This is a very important part of the new "us-them" discourse in contemporary South Arica. South African diasporic people on the Web constantly complain about this, as seen in the posting by "alroba" (accessed 29 October 2007):

Another Pale native you sound like another ANC mouthpiece. All the ills of SA stem from the past. Everything wrong will still be blamed on apartheid. Bad policing, crumbling infrastructure, unemployment etc all due to apartheid we're told. As far as 
BEE is concerned. My brother in law has had a business for 25 years. All of a sudden he has to have black shareholders/directors in order to get contracts. He closed his business, put about 20 people out of work and came to NZ. BEE just means we, the black majority, will have a share of everything without working for it

Interestingly, in 1994, the white South African narrative actually encoded a sense of optimism built upon the notion that blacks and whites were going to develop a mechanism to share the country and learn to work together. This optimism only lasted a few years. It has been replaced with a new white South African narrative which encodes the idea that the county has been lost to barbarians. Effectively the old pre-1990 narrative that Western culture is culturally superior to black-African culture has reasserted itself. The idea that South Africa is now run by "barbarians" has become enmeshed with the idea that since 1994 the criminal justice system and health services have collapsed; violent crime has become rampant and corruption has become endemic. The appearance of infrastructural collapse (e.g. urban decay, spreading informal slums and the collapse of the country's electrical grid) has served to boost the idea that a developed Western country has been lost to barbarians. This has become a feature of the "white talk" deployed by South African diasporic people on the Web. An example is the posting by "Saffer2005" (accessed 2 June 2007):

The opportunity that so many of us dreamed about - the opportunity that seemed possible to build a new nation, undivided, equal opportunity for all, regardless of race, sex or creed. And of working shoulder to shoulder to make South Africa a world-class country to be proud of. However - what have we seen evolve over the last twelve years? AA, $\mathrm{BEE}$ and racism against whites, government corruption, rampant crime, and a crumbling infrastructure. And this is not about bringing back the old "regime".

In the case of Serbia, along with the image of "historical superiority," one sees the creation of the image of cultural and civilizational superiority. The Serbs were similarly, representing themselves as a nation with a "centuries long tradition," they were "freedom lovers". Specifically, on the web, there were some Serbian voices nostalgically looking back into the past Serbian heroic times. As "Biljana" points out (accessed 5 February 2007), "We the Serbs are the oldest nation in Europe, with our own original alphabet, language, culture... with the role of being a protector and defender of Europe from the armies from the East. And look at us now. Being forced to feel subordinated!' In these narratives, Serbian resentment presumes a neurotic type of identity, characterized by feelings of defeat because of the loss of the desired state, and by feelings of injured pride that the nation lags behind others, especially Western Europe. This national identity was built through the centuries by specific historical and geographical conditions of being subordinated. There are two topics of resentment as articulated. The first one is Yugoslavia is a Serbian delusion. According to this theme, Serbs were naively duped into accepting Yugoslavism and the fraternal bonds of its other nations, while the Slav brothers were continually building their ethno-national states on the bones of dead Serbs who fought in wars of liberation. The Serbs lost considerable "historical time" in coming to the realisation that Yugoslavia was a Serbian delusion. They had everything to lose in accepting the Yugoslav project, and other nations had everything to gain. The Serbs were the victims of their own futile 


\section{GMJ - AE 2010 Vol 4 (1)}

Yugoslavism. The second one is the conspiracy against the Serbs: During their entire Yugoslav history, Serbs were exposed to the conspiracy of everyone who played the leading roles in Yugoslav decision making and who implemented Yugoslavia's anti-Serbian policy. In these narratives, Serbs are the losers, because they are the only ones who do not have a state proper. They historically win at war, but lose in peace. All their war victories were canceled out in peace settlements. As "zigolo" pointed out (accessed 13 September 2007):

Serbhood... the Serb people have been suffering for decades because of the communist idea - in three wars, three million souls... According to all demographic and statistical data, today, there would have been about 60 million of us... The enemy which is clear to us such as the Muslims, and the International Community... still want to destroy us. Muslims are not even a nation - and the Serbs had their state 700 years ago. Only within this time context can we understand all their complexes...

Many statements emphasised the need for Serbian unity inside and outside Serbia, virtue, and religiosity as central to the Serbian way of life. The narratives clustering around the memories of Serbian victimhood form an analytically connected cycle of Serbian national narratives. In this politics of (ethnic) memory, the symbolic is firmly built upon an anger and resentment.

Most of the posts stress the word "domovina [homeland]" and some of the participants phrased their perception of Serbia in a way reminiscent of nationalism as a cultural movement, a kind of a yearning for the days of old, a wish to preserve the local language and culture. Serbia is associated with culture and tradition, and sometimes it was nostalgically connected with past, idyllic, times - where "there was collectivity..." A lot of them also expressed disillusion and alienation from the motherland, as evident in the post by "Mila" (accessed 4 July 2007):

I am saddened by the fading glory of this nation, that has lost so much territory in the past" and evinced nostalgia for the Serb nation: "Serbia was once rich, honest, beautiful, unpolluted, with the most tasteful plums and kajmak. Now, it is different. Things have changed. We lost.

Culturally, the self-perception of being superior, passionate and irrational, and the practice of Serbs acting as witnesses to their own oppression are crucial mechanisms through which the very idea of Serbian-ness is performed and reified. This feeds directly into the anger and resentment feelings, as posted by “Ceca1” (accessed 20 January 2008):

Serbia, represents the greatest and deepest base of the European cultural memory, and the people of Serbia are historically the last guardians of this culture. Collectively, I think Serbs are truth loving and just... we cannot be compared with any other nations. We have certain qualities that make us unique. And no one can understand us... For the third time the West wants to force upon an intricate multi-ethnic mosaic the logic of the GalloAmerican, civic-republican, assimilationist, or "melting pot" - but of course ethnically flavored-nation-state. It has ended twice in disaster and it will end so again. 
A unified "Serbia" was portrayed as a warm motherland in the past, but now, things have changed considerably. There is a widespread recognition that life in the West is materially much safer, more comfortable and peaceful, and that the West is materially rich, but spiritually poor. These values get reversed when Serbian identity is defined, as expressed by "Jovo" (accessed 22 May 2008): "Serbs were proud and passionate people. The global forces have changed all that. Things are different now. I feel as if I do not belong anywhere anymore. Serbia has become a western colony itself, let's be honest about it."

Many posts also point to the questions of why the West misunderstands the Serbs. As posted by "Milica" (accessed 24 November 2007):

Many people outside Serbia fail to make a distinction between Serbs who supported Milosevic and those who did not: we feel on the one hand that the whole world perceives all Serbs to be somehow complicit in the aggression that has been waged over the last decade. And that we have been painted with the brush of the policies of a government they have disagreed with from the very beginning. Also, we, Serbs in exile, we are becoming increasingly frustrated. We cannot go home and no country wants us. I don't want to go home, things have changed too radically.

Overall, in both cases, white South African and Serb, the narratives of loss, victim-hood and anger prevail while expressing the feelings about "motherlands". In the next section, we attempt to analyse these feelings of grief and grievance.

\section{Discussion: Feelings of grief \& grievance}

The postings to the Web by white South African and Serb diasporas suggest a powerful sense of grievance. On the one hand there is a sense of loss (about "losing their country"). But the postings go beyond "loss' and "grief"; they also encode strong anger about their country being "lost" or "taken away". The Serbs are resentful about the loss of the territory they perceived as "theirs" - parts of Croatia, Bosnia, and, of course, Kosovo. The white South Africans are angry that (black) "others" now have control/ownership of an infrastructure which they see as having been developed by white South Africans (Parliament, houses, farms, schools...). It is a grievance that seems to be associated with some sort of envy that "others" have now taken control of, and are now using, "their" (white) spaces. The process by which the "others" have taken over these spaces is not deemed legitimate, and the "others" are seen to be defiling and damaging these spaces.

However, the postings on the Web may not be representative of all white South Africans or Serbs because the postings are made by a self-selecting group of diasporic people. It is the angry diasporic people - those with a deep sense of grievance - who most clearly use the Web to vent frustration (see diagram below). 
GMJ - AE 2010 Vol 4 (1)

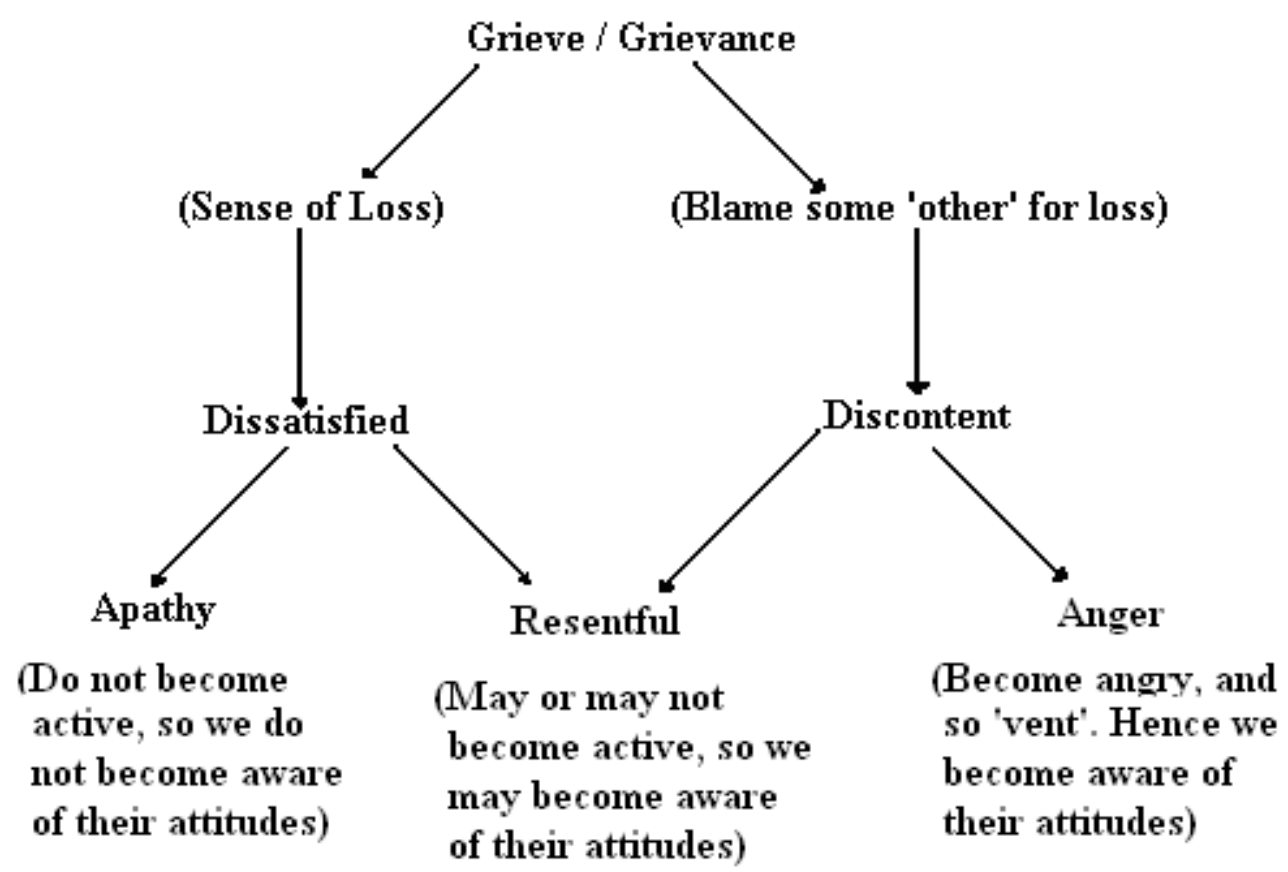

Those who grieve are simply experiencing a sense of loss. This generates a sense of loss and dissatisfaction which is not directed at an external "other". Rather, it leads to apathy (grounded in the experience of "loss"). However, grief slides into grievance when some "other" is blamed for the loss. This "other" (or "others") can then become a target for active discontent. One is no longer simply apathetically grieving or sad; one can become actively angry. This anger can be targeted at the "other" deemed responsible for one's loss and pain.

We suggest here that diasporic peoples' angry relationship to this "other" is perhaps grounded in envy - because diasporic people are very concerned about the pleasure that somebody else now has, when s/he "enjoys' their homeland. They associate the pleasure with "the ones who are now living in their country" and in that, they imagine the pleasure that someone else has while living in their homeland. In Copjec's argument (2004), when one experiences jealousy, one worries about losing something that one already has. However, one feels envy when one is concerned about the pleasure that someone else has. In her words, "Jealousy fears to lose what it has; envy is pained at seeing another have that which it wants for itself." And, furthermore, "jealousy is grounded in the possession of a certain pleasure, whereas envy stems precisely from a lack of it" (Ibid, 2004:160).

Envy, grievance and anger are linked through an experience of powerlessness - both Serbs and white South Africans feel powerless to prevent the "other" (as rivals) from using that which they perceive to be "theirs". Their sense of "loss" thus triggers sadness (for a world that is no more), envy and resentment (that their rivals now enjoy "their world"), and anger (about changes that are perceived as unjust). The resultant complex mix of disempowerment, rivalry, envy, anger and sadness results in these diasporic people generating a web-presence driven by grieving (which 
encodes a loss that cannot be recovered) and grievance (which encodes a need to "do something", even if this something is just "venting" one's anger. This venting may produce a sense of re-empowerment - gained from feeling one has hit back at one's tormentors (the rival "others"). In a sense, then, both Serbs and white South Africans have for centuries been locked into relationships with others characterized by rivalry. It is rivalry over:

- power (ability to make decisions/decision-making)

- resources

- land (land is important in their concept of nation)

According to the posts, they believe they have acquired the right to certain land/resources (because of "history") and they share a sense of ownership. Now if others gain control over these resources/land, it forecloses your ability to use these resources/land in the present and in the future.

This means all you have left are your memories of past control/ownership of resources/land. If one focuses on the past this generates grief (over the loss of land/resources/power). But if one focuses on the present (or future) it generates:

- grievance (if you think the loss was caused by the system being "rigged" against you = injustice about the loss)

- $\quad$ anger at the loss

- $\quad$ envy (when one sees others using "your" land/resources).

\section{Conclusions}

As argued in this paper, with the collapse of two regimes, a particular type of "anger" erupted on-line among Serbian and white South African diasporas with a resentment and envy about the current situation in their former countries. Both online diasporic communities, we suggest, voice their arguments in the language of anger. These diasporic sites speak of the ongoing griefe and assert that they have been the victims of "unjust" history and globalisation. Effectively these diasporic people appear to be trying to construct a sense of belongingness, or perhaps more accurately trying to reconstruct a sense of the belongingness they have lost through migration. They appear to be (traumatised) lost souls searching for a lost (mythical?) gemeinschaft - i.e. searching for the comfort of belonging to a familiar community. The irony is that the communities they are seeking no longer exists because the gemeinschaft they seek is based on memories grounded in another place and another time. Since diasporic people are physically separated from their homelands and with that, from the conflicts, they are experiencing different emotions and developing different feelings - they feel and express anger, frustration and alienation. In both cases, (re)production of the intense feelings is one of the main axles of the diasporic project on-line. Also, not surprisingly, collective history and culture are the cement which ties diasporic communities to each other. 
The use of the Internet here is based on some retrieval of an idealized past - and is not able to create and assert a position for the present, and is not able to accommodate the inconsistencies and contradictions of contemporary life.

To end, the cyber diasporic communities provide for diasporic groups - a "cultural" place that they claim as their "own", in which they do not feel as "marginalized". The need for regular social interaction among the members of immigrant groups and, the need to keep their cultural and linguistic heritage relevant, could be the force for the development of the community. While exchanging messages in their own language, sharing common memories and angry discourse, those cyber spaces create the sense of a particular type of belonging.

Authors' details

Eric Louw, University of Queensland, Australia, has previously taught at a number of South African universities and worked as a journalist on the Pretoria News. He has published widely in the areas of political communication, and the South African media. His books include The Media and Political Process (Sage); The Media and Cultural Production (Sage); and Roots of the Pax Americana (Manchester University Press).

Zala Volcic is a Postdoctoral Fellow at the Centre for Critical and Cultural Studies, and a Senior Lecturer at the School of Journalism and Communication at the University of Queensland, Australia. She is interested in the topic of global communication, media, nationalism, and identities. Her work was published in Canadian Journal of Communication, Social Semiotics, Critical Discourse Studies, International Communication Journal, Gazette, and Critical Studies of Media Communication.

\section{References:}

Aksoy, A. 2007 The possibilities of transnational Turkish elevision. Accessed from the World Wide Web: http://www.photoinsight.org.uk, 2007-12.

Appadurai, A. 2000. Modernity at large: cultural dimensions of globalization. Minneapolis, MN: University of Minnesota Press.

Chopra, R. 2006. Global primordialities: virtual identity politics in online Hindutva and online Dalit discourse. In: New Media and Society, 8(2), pp:187-206.

Chouliaraki L. 2006. The spectatorship of suffering. London: Sage.

Copjek, J. 2004. Imagine there is no woman. Boston: MIT Press.

Evans, M. 2006. Virtually South African. Paper presented at the End of the Rainbow Conference, Stellenbosch, 2006-07-06.

Couldry. N. 2003. Media rituals: a critical approach. London: Routledge. 
Georgiou, M. 2001. Negotiated uses, contested meanings, changing identities: Greek Cypriot media consumption and ethnic identity formations in North London. Unpublished Thesis. London: University of London.

Giddens, A. 1991. Modernity and self-identity: self and society in late modern age. Cambridge: Polity Press.

Gillespie, M. 1995. Television, ethnicity and cultural change, London: Routledge.

Jensen, L.J. 2003 Public spheres on the Internet: anarchic or government sponsored - a comparison.In: Scandinavian Political Studies 26(4): 349-74.

Jones, S.G. (ed.) 1995. Cybersociety: computer-mediated communication and community. Thousand Oaks, CA: Sage.

Joubert, T. 2006. Enticing the "scatterlings" of South Africa to return. Report by Research Surveys Pty Ltd., March.

Karim, H. K. 2003. The Media of Diaspora, New York: Routledge.

Kollock, P. \& Smith, M.A. 1999. Communities in Cyberspace, in: M. Smith, M. \& Kollock, P. (eds) Communities in cyberspace, pp: 3-25. New York: Routledge.

Koser, K. \& Lutz.H. 1998. The new migration in Europe: social constructions and social realties. London: Macmillan.

Lopusina, M. 1998. Svi Srbi sveta - Srbi u Dijaspori. Beograd: IP Prosveta.

Louw, P.E. \& Mersham, G. 2001. Packing for Perth: The growth of a Southern African diaspora, Asian \& Pacific Migration Journal 10(2).

Louw, P.E. 2004. The rise, fall and legacy of apartheid. Westport: Praeger.

Mbeki, T. 2003. The full meaning of liberation, Africa define yourself. Cape Town/Johannesburg: Tafelberg/Mafube.

Mbeki, T. 2004. State of the Nation Address, Parliament, 6 February

Miller, D. \& Slater, D. (2000) The Internet: an ethnographic approach. Oxford: Berg.

Morley, D. \& Robins K. (1995) Spaces of identity: global media, electronic landscapes and cultural boundaries. London: Routledge 
Naficy, H. 1993. The making of exile cultures: Iranian television in Los Angeles. Minneapolis: University of Minnesota Press.

Naficy, H. 1999. Home, exile, homeland: film, media and the politics of place. New York, London: Routledge.

Rai, A.S. 1995. India on-line: electronic bulletin boards and the construction of Hindu identity, Diaspora 4(1), Pp: 31-57.

Rheingold, H. 1993. The virtual community: homesteading on the electronic frontier. Reading, MA: Addison-Wesley.

Rieff, D. 1999. In defence of Afro-Pessimism, World Policy Journal, XX (4).

Schmitter Heisler, B. 2000. The sociology of immigration: from assimiation to segmented integration, from the America Experience to the Global Arena. v: Brettell C., Hollifield, J.F. (ur.).: Migration Theory: Talking across the Disciplines. Routledge: New York, Pp: 77-96.

Skrbiš, Z. 1999. Long-distance nationalism: diasporas, homelands and identities. Aldershot: Ashgate Publishing Ltd.

Sreberny, A. 2002. Connectivity and collectivity: diaspora and mediated identities. In: T. Tufte, T. \& Stald, G. (eds.). Global encounters. Luton: University of Luton Press

Steyn, M. 2005. White talk: White South Africans and the management of diasporic whiteness. In: Lopez, A.J. Postcolonial Whiteness. Albany: New York University Press.

Tonnies, F. 1955. Community and association. London: Routledge \& Kegan Paul.

Tynes, R.2007. Nation-building and the diaspora on Leonenet: a case of Sierra Leone in cyberspace. In: New Media and Society 9(3): 497-518.

Van Aardt, P. 2006. Million whites leave South Africa - Study. Fin24 [Online], Available fin24.com.

Van Jaarsveld, F.A. 1971. Van Riebeeck tot Verwoerd. Johannesburg: Voortrekkerpers.

Verhulst, S. 1999. Diasporic and transnational communication: technologies, policies and regulation. Javnost/ The Public 6(1): 29-36.

Volčič, Z. 2007. Scenes from last Yugoslav generations: the long march from Yugo-Utopia to nationalisms. In Cultural Dynamics, 19 (1): 67-89. 


\section{GMJ - AE 2010 Vol 4 (1)}

Volčič, Z. 2008. Mediji in identiteta: (Medijski) Prostori Identitete in pripadnosti. FERI: Maribor.

\section{Notes}

'The term 'White South African' is used primarily as a 'cultural' marker. So although the term 'white' incorporates 'race', it also transcends 'race'. The term refers to two groups of people who speak different languages (Afrikaans and English) and who have a history of conflict, but who have jointly established a shared African society that is culturally European-derived (much as 'Americans' have created a European-derived society/culture in the USA). We needed to find a term that incorporated both Afrikaners and Anglos, because they have historically built a shared ociety (called 'South Africa'). What Afrikaners and SA-Anglos share is European descent. However, 'European' implies 'colonial'; and since 'white South Africa' has a 350-year existence it is clearly no longer a colonial phenomenon that is tied to Europe. Hence 'white' is a better descriptor than 'European'.

${ }^{\text {ii } H o w e v e r, ~ n o t ~ a l l ~ w h i t e s ~ w e r e ~ r i c h / a f f l u e n t . ~ I n ~ b r o a d ~ t e r m s ~ o n e ~ c a n ~ c e r t a i n l y ~ s a y ~ A f r i k a n e r s ~ w e r e ~ " p o l i t i c a l l y ~}$ dominant" in apartheid South Africa and that Anglos were "economically dominant". But this did not translate into economic affluence for all whites. There were rich whites, middle class whites and working class whites.

iii Again, the speed of communication and technology accessibility makes it possible for diasporic people to reinvent and sustain relations with their homelands. This furthermore means that they can participate in developments in their homelands and shape their own feelings and connections. However, their identities are also being shaped by categories such as race, class, ethnicity and gender. The South African and Serbian cyber diasporas gather members that differ across gender, age, class, level of education, or a country of settlement. We will not be discussing these here, since we focus on overall comparisons.

${ }^{\text {iv }}$ These websites were understood as 'texts' located in economies of technology and culture that are at once economies of power. 